\title{
Physics Education: Effect of Micro-teaching Method Supported by Educational Technologies on Pre-service Science Teachers' Misconceptions on Basic Astronomy Subjects
}

\author{
Fatih Gurbuz \\ Correspondence: Fatih GURBUZ, Bayburt Faculty of Education, Bayburt University, Bayburt, Turkey \\ Received: October 14, 2015 \\ Accepted: October 20, 2015 \\ Online Published: October 21, 2015 \\ doi:10.11114/jets.v4i2.1140 \\ URL: http://dx.doi.org/10.11114/jets.v4i2.1140
}

\begin{abstract}
The purpose of this research study is to explore pre-service science teachers' misconceptions on basic astronomy subjects and to examine the effect of micro teaching method supported by educational technologies on correcting misconceptions. This study is an action research. Semi- structured interviews were used in the study as a data collection tool to identify pre-service teachers' misconceptions on basic astronomy subjects. The data gathered from the interviews were interpreted via descriptive analysis. The research was carried out with 20 pre-service teachers studying in the $4^{\text {th }}$ grade in Faculty of Education, Department of Primary School Science Teaching at a university located in Eastern Black Sea Region, Turkey. 20 pre-service science teachers who participated in the study developed materials about basic astronomy subjects and they used micro-teaching method supported with appropriate educational technologies for 12 weeks. All the implementations were carried out under the supervision of the researcher and after the implementations, the researcher and the pre-service teachers watched the video recordings together and necessary feedback was given. At the beginning of the research, pre-service teachers who made up the sample of the study had various misconceptions about basic astronomy subjects; however, it was found that these misconceptions which were detected were corrected with micro-teaching method at the end of the research study. The study was completed with recommendations regarding using educational technologies and micro teaching method and correction of misconceptions.
\end{abstract}

Keywords: physics education, astronomy, misconceptions, micro-teaching method, action research, pre-service science teachers

\section{Introduction}

Physics course, particularly due to abstract concepts, consists of subjects which are rather difficult to understand and explain (Gürbüz, 2008). Moreover, among the topics studied are concepts about astronomy. Before human beings begin their educational life, they can see the sky with a naked eye and they continue living with second hand information about phenomena occurring in the sky and giving meaning to them with their interpretations.

The methods which are frequently encountered in everyday life are unfortunately responsible for misconceptions within the individuals and they are really difficult to compensate. (Yürük, Çakır and Geban, 2000). If such misconceptions occur within teachers who are key elements of education, this knowledge which is against scientific facts passes down the generations and continues like that.

Astronomy concepts are very important for physics education. Science teachers are the teachers who will enable students studying in secondary schools to learn basic astronomy concepts. Thus, before pre-service science teachers begin to work as a science teacher, it is important that their misconceptions on astronomy concepts are eliminated. However, the research studies conducted in our country revealed that (Emrahoğlu and Öztürk, 2009; Kalkan, Kalkan and Ustabaş, 2006; Orbay and Gökdere, 2006) pre-service science teachers had various misconceptions about astronomy.

A number of studies have been carried out on children and adults in many countries which have knowledge about the importance of astronomy subjects and astronomy teaching (Baxter, 1989; Bisard, Aron, Francek, \& Nelson, 1994; Bryce and Blown, 2006; Ekiz and Akbaş, 2005; Emrahoğlu and Öztürk, 2009; Kalkan, Kalkan and Ustabaş, 2006; Keçeci, 2012; Kikas, 1998; Mali and Hove, 1979; Nussbaum, 1979; Orbay and Gökdere, 2006; Şahin, 2001; Trumper, 2001; Ucar and Demircioglu, 2010-2011; Ucar, 2012; Ünsal, Güneş and Ergin, 2001; Vosniadou And Brewer, 1992; Zeilik, 
Schau and Mattern, 1998). When these studies are examined, it is found that many subjects like the students' understanding levels of astronomy subjects and students' knowledge level, misconceptions found in students about astronomy subjects, and evaluation of astronomy curriculum have been explored. These research studies have covered a wide range of levels, beginning from primary school to university level. It is required that astronomy misconceptions found in pre-service science teachers must be identified in astronomy course included in curriculum and they must be corrected. The most effective way to realize this is to carry out an action research. An action research is learning by doing of a group of people identifying a problem, doing something to resolve it, seeing how successful their efforts are, and if not satisfied, trying again (O'Brien, 2001). Generating theoretical knowledge is not among the priorities of action research because the main purpose of action research is to improve the implementations carried out. Another purpose of action research is to actively engage participants with research and to offer opportunities for them to learn by doing with direct and volunteer based implementations. Because an action research is carried out in real world circumstances, one of its purposes is to solve real problems. Because the problems are directly solved, action research can eliminate the resistance that might occur during the process of transferring the solutions obtained into practice (Aksoy, 2003). Micro teaching is one of the most efficient ways to solve the observed problems directly and at first hand during teaching-learning process in action research because micro teaching focuses on specific pre-service teachers' behaviours (Sevim, 2013).

It was identified in the research studies conducted using micro teaching method that (Bell, 2007; Dennick, 1998; Hall and Leveridge, 1983; I'anson, Rodrigues and Wilson, 2003; Kinchin and Alias, 2005; Mellon and Dence, 1971, Kpanja, 2002; Metcalf, Hammer and Kahlich, 1996; Saunders, Gall, Nielson and Smith, 1975; Sevim, 2013; Simbo, 1989), this method had a quality which emphasizes the relationship between the theoretical and practical knowledge and therefore this method has an important place in getting prepared for teaching profession. While an individual is transferring the knowledge, he has to think himself and build a consistent link between the knowledge. Undoubtedly, it will not be able to build a consistent relationship between the knowledge with misconceptions. Therefore, during the implementation of micro-teaching, pre-service teachers are expected to notice existing misconceptions and make an effort to eliminate such misconceptions.

When literature is examined, it is found that there are many studies conducted on micro-teaching method and astronomy subjects. However, a study which uses micro-teaching to eliminate misconceptions about basic astronomy subjects within pre-service teachers has not been found. The most important reason to carry out this research is the necessity that pre-service teachers who will shape our future can begin their teaching profession after the possible problems they have are solved with pre-service training. In this regard, it is considered that this study will make contributions to the other research studies which will be conducted in this field.

\section{Methodology}

This study which aims at determining the misconceptions of pre-service science teachers on basic astronomy subjects and examining the effect of micro-teaching method which is supported by educational technologies on eliminating misconceptions is an action research. Because the research aimed at reaching a solution for a problem about misconceptions during the implementation, action research, one of the interpretive research methods, was chosen as a method.

Mills (2003) developed the following framework for an action research: describe the problem and area of focus, collect data, analyse data, interpret data, and determine the action to be taken. Figure I show the relationship between these stages within the framework of action research.

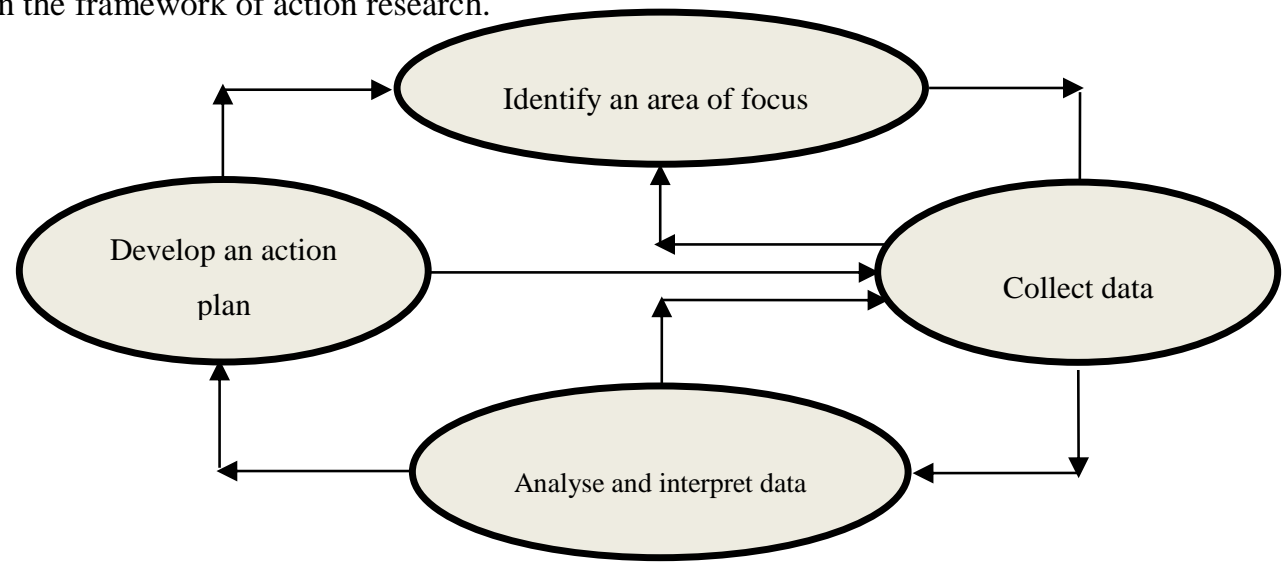

Figure 1. Action Research Cycle 
This research study was based on the stages of action research developed by Mills (2003) in Figure I and it was carried out by the researcher himself.

\subsection{Identify an Area of Focus}

The researcher individually carried out the courses of pre-service teachers in the sample group such as general physics III, introduction to modern physics, physics special topics, programming and planning science technologies. It was observed in these courses that the sample group held various misconceptions about physics courses. Moreover, the researcher observed that students had some misconceptions about basic astronomy subjects in the astronomy course which he had thought in the previous years. Regarding the solution to this problem identified, the researcher had interviews with faculty members from the field and they suggested that he should use micro-teaching method because pre-service teachers were the sampling who had problems.

\subsection{Collect Data}

Semi-structured interview forms were designed to identify the pre-service teachers' misconceptions on basic astronomy subjects. The reason why the interview form was used is that it allows for an in-depth analysis of pre-service teachers' knowledge on basic astronomy subjects. The interview form developed was firstly used to identify pre-service teachers' misconceptions just before the implementations started. The same interview form was reused to check the change with the misconceptions soon after all implementations which were actualized throughout the research were completed.

\subsection{Analyse and Interpret Data}

Data analysis comprises one of the most important steps of action research. Data analysis and interpretation are the steps in which the researcher summarizes the clear, accurate and reliable data collected. In this stage, while the researcher collects and analyses data, he describes the themes and categories uncovered.

During the research process, the data were collected via semi-structured interviews. The research lasted 12 weeks. The data were obtained via interviews and they were recorded. During the evaluation of this recorded data, they were presented without making any changes so that they could support the data. Finally, all the data gathered, analysis, and interpretations within the context of the research were checked both by the researcher and by the experts from the field. Thus, the research findings were enriched with different perspectives and opinions.

\subsection{Develop an Action Plan}

Yıldırım and Şimşek (2013) emphasized that within the framework of analysis and interpretation of data obtained in this stage, a solution plan or alternative action plan related to the existing implementation process can be developed.

After the pre-service teachers' misconceptions about basic astronomy subjects were identified, the lessons were taught using micro-teaching method for twelve weeks. Regular meetings were organized with pre-service teachers and necessary discussions and suggestions were made. Considering the data obtained after the implementations, expert opinions were received again and the research was completed after reaching the conclusion that the problem was resolved.

\subsection{The Sampling of the Research}

The research was carried out at a university located in Eastern Black Sea Region in Turkey. The participants composed of 20 fourth year pre-service teachers studying in Science Education Program in the Department Primary School Teaching. Purposeful sampling was used in the study. Smaller sample size is used in qualitative research for in-depth analysis. Therefore, purposeful sampling is preferred rather than random sampling (Munn, Johnstone and Holigan, 1990). In this sampling, the criteria important for the sampling are determined and the sampling chosen according to the criteria is considered to represent the population with its all qualities (Yin, 2003). Out of 20 pre-service teachers in the sampling, 12 of them are females and 8 of them are males.

\subsection{Data Collection Tools}

Semi-structured interview consisting of eight questions was designed to identify the pre-service science teachers' misconceptions on basic astronomy subjects in the research study. While the questions in the interview form were developed, the relevant literature was reviewed and the questions were organized regarding the possible misconceptions. The interview form consisted of ten questions at the first step and it was examined by 3 faculty members from the field. Then, two questions were extracted from the interview, one question was revised, and finally the interview consisting of eight questions was finalised. The interview was carried out with the pre-service teachers before the implementation started. The interviews were performed in two steps, which included the following:

1. Pre-service teachers were informed about the reasons for the interviews. Next, the differences between misconceptions and incomplete-incorrect information were mentioned. While the pre-service teachers were expressing their opinions 
about the questions in the interview form, they were particularly asked to specify the questions which they were not familiar with the answer or if they had no idea about the subject, they would answer the question asked as "no idea about the subject". Although pre-service teachers knew the researcher for years, it was noticed that they were excited. Therefore, the researcher talked with them on topics that were not research related and tried to reduce their excitement. The interviews did not start until it was made sure that the pre-service teachers were ready.

2. In this stage, the pre-service teachers were asked the questions in the questionnaire. In line with the responses, sub-questions were asked to seek in-depth explanations.

Each interview lasted 20 minutes. Some abbreviations were used when the findings obtained from the interview data were presented. What these abbreviations stand for was given below.

R: Researcher, PST: Pre-service science teacher, $\mathrm{PST}_{1}$ : The first pre-service teacher, $\mathrm{PST}_{2}$ : The second pre-service teacher, $\mathrm{PST}_{3}$ : The third pre-service teacher, $\mathrm{PST}_{4}$ : The fourth pre-service teacher...

\subsection{Data Analysis}

Validity in action research means that the data collected creates a fairly true picture with observations. Reliability means to experience a highly credible data collection and analysis processes (Mills, 2003). The interviews conducted face-to-face with the participants by the researcher were recorded with a recorder after obtaining informed consent from the participants and the participants were assured that the entire data recorded would be deleted after the study was completed to provide reliability and validity in the research. The per-service teachers listened to the data recorded after the interviews and they were asked whether they would like to add or correct anything. Then, they approved that the recordings were accurate and complete. The data collected from the interviews performed with pre-service teachers were analysed using content analysis. Content analysis is a technique for systematically describing and summarizing a written text into smaller text chunks and categories based on certain codes (Büyüköztürk, Kılıç Çakmak, Akgün, Karadeniz and Demirel, 2013). In content analysis, similar data are collected within the framework of certain concepts and themes, organized comprehensibly, and interpreted (Yıldırım and Şimşek, 2013). Regarding this technique, the data were categorized and evaluated. Experts from the field watched a certain number of videos and recordings for the categories and they expressed their opinions. The data were analysed and their percentages (\%) and frequencies (f) were taken. The responses of pre-service teachers who participated in the study were supported by direct quotes. In the next section of the study, the findings obtained from the analyses were presented widely.

\section{Findings and Discussion}

\subsection{Findings Obtained from the Interviews Carried out at the Beginning of the Research}

The findings obtained as a result of the analysis of responses to the interview questions carried out to identify pre-service teachers' misconceptions on basic astronomy subjects were presented below. First, the analysis of interview questions before micro-teaching was presented. Then micro-teaching implementations and the analysis of interview questions administered after the instruction were presented. Because the responses of pre-service teachers to the questions were so varied and they could be grouped into different categories before micro-teaching, they were presented in tables. However, as the responses to the questions were so similar to each other after micro-teaching, they were not presented in tables but they were described and given directly.

Question 1: "What is a star?"

The responses of the participants were presented in Table 1.

Table 1. Analysis results of the participants for Question 1

\begin{tabular}{cccc}
\hline \multirow{2}{*}{ INTERVIEW QUESTION } & & \multicolumn{2}{c}{$\begin{array}{c}\text { FREQUENCY and } \\
\text { PERCENTAGES }\end{array}$} \\
\cline { 3 - 4 } & CATEGORIES & f & $\%$ \\
\hline \multirow{2}{*}{ What is a star? } & It is a planet which reflects the light it receives from the Sun. & 8 & 40 \\
& They are celestial bodies that can emit heat and light. & 7 & 35 \\
\hline
\end{tabular}

When the pre-service teachers' responses to the question "What is a star?" which aimed at identifying their misconceptions on star were examined, it was revealed that 15 pre-service teachers had misconceptions but five teachers could answer the question "What is a star?". Examples from the responses given for each category were quoted to explain the existing situation.

$-P S T_{1}$ : "Stars are planets which have the ability to emit light."

$-R$ : "Well, do you think that stars are planets?" 
$-P S T_{1}$ : "Yes. In fact, during the formation of the universe, all the planets could emit light, but some planets like the Earth cooled and lost their feature. Planets which we call star have not cooled yet; that's why they still can emit light."

-PST 7 : "Celestial bodies which we call a star are objects which can emit light."

-R: "How can stars emit light by themselves?"

-PST 7 : "Due to fusion reactions which occur in their structures, stars can emit heat and light around themselves."

-PST : "Some planets are very close to the Sun and we call them a star."

-R: "Do you think that the only fact that makes them a star is being close to the Sun?"

$-P S T_{9}$ : "I do not know if they have other features. However, in order to see them, they must be reflecting the light they receive from the Sun. That's why they look bright because they reflect the light they receive from the Sun. They are called stars because they look brighter than other planets."

When pre-service teachers' misconceptions identified about stars are examined, it is found that they could not completely distinguish star and planet concepts from each other. It is considered that because the pre-service teachers who participated in the study did not receive adequate education on basic astronomy subjects before, their lack of education had an effect on this situation.

Question 2: "What comes to your mind about space and universe?”

The responses of the participants to question 2 were presented in Table 2.

Table 2. Analysis results by the participants for Question 2

\begin{tabular}{|c|c|c|c|}
\hline \multirow{2}{*}{ INTERVIEW QUESTION } & \multirow{2}{*}{ CATEGORIES } & \multicolumn{2}{|c|}{$\begin{array}{c}\text { FREQUENCY and } \\
\text { PERCENTAGES }\end{array}$} \\
\hline & & $\mathbf{f}$ & $\%$ \\
\hline \multirow{3}{*}{$\begin{array}{l}\text { What comes to your mind about } \\
\text { space and universe? }\end{array}$} & Universe and space are both the same concepts. & 12 & 60 \\
\hline & You can see space with a naked eye but universe cannot be seen. & 7 & 35 \\
\hline & Human beings can go to space, but they cannot go to universe. & 1 & 5 \\
\hline
\end{tabular}

When the pre-service teachers' responses to the question "What comes to your mind about space and universe?" which aimed at identifying their misconceptions about space and universe were explored, it was understood that all pre-service teachers had misconceptions. Examples from the responses given for each category were quoted to explain the present situation.

-PST: "These are the two concepts used for the places which human beings can see with a naked eye or with the help of the telescopes or places which have not been seen yet or whose light has not reached us yet."

$-R$ : "Can you please give more information about this?"

$-P S T_{8}:$ "Well, space is the place that scientists can see with the help of telescopes they use or space shuttles. The places which they cannot see is called universe."

$-P S T_{12}$ : "Especially with the development of technology, human beings are able to travel to outer space. Early on in space explorations, the space concept did not exist but after the space travel started, the place where they could go to was called space. However, universe is too far to travel."

$-P S T_{18}:$ "There is no difference between space and universe."

-R:" Do you mean that space and universe are the same concepts?"

$-P S T_{18}$ : "Yes, because the concepts of space and universe which we frequently use in everyday life mean the same."

It is considered that because space and universe concepts are frequently used interchangeably in everyday life, they might cause the identified misconceptions to occur.

Question 3: "What is a planet?"

The responses of the participants to question 3 were presented in Table 3.

Table 3. Analysis results of the participants for Question 3

\begin{tabular}{|c|c|c|c|}
\hline \multirow{2}{*}{ INTERVIEW QUESTION } & \multirow[t]{2}{*}{ CATEGORIES } & \multicolumn{2}{|c|}{$\begin{array}{l}\text { FREQUENCY and } \\
\text { PERCENTAGES } \\
\end{array}$} \\
\hline & & $\mathbf{f}$ & $\%$ \\
\hline \multirow{3}{*}{ What is a planet? } & Planets are stars which completed their life. & 8 & 40 \\
\hline & It is a celestial body which has an atmosphere. & 9 & 45 \\
\hline & It is a celestial body which is in orbit around a star and has some conditions. & 3 & 15 \\
\hline
\end{tabular}


When the pre-service teachers' responses to the question "What is a planet?" asked to identify their misconceptions on a planet were examined, it was discovered that 17 pre-service teachers had misconceptions but three teachers could answer the question correctly although they could not explain it exactly. Examples from the responses given for each category were quoted to explain the existing situation.

$-P S T_{20}$ : "Stars which do not emit light and heat are called a planet."

-R: "Can you please clarify it?"

$-P S T_{20}$ : "Stars have existed since the existence of the universe. However, some of them cool due to some reasons and they do not emit light and heat. Such stars are called planets. In other words, planets are stars which cooled."

$-P S T_{13}$ : "Some celestial bodies which are in orbit around the sun and bear some condition as far as I remember are called a planet."

-R: "You said some conditions. Can you explain these conditions?"

$-P S T_{13}$ : "They must move in elliptical orbits which have the sun in the centre, they must rotate around their axis and I suppose they should have a shape."

$-P S T_{15}$ : "There are a lot of celestial bodies in the universe. Some of them are quite larger and they have an atmosphere. These celestial bodies with an atmosphere are called a planet."

-R: "Do you mean that if a celestial body does not have an atmosphere, it is not a planet?"

-PSTS 15 : "Yes. If it were not like that, there would be a lot of celestial bodies in the space like meteorites. So, we had to call all of them planets. Therefore, the celestial bodies with large volume and mass have an atmosphere due to gravity and they are called a planet."

When the pre-service teachers' misconceptions on planets are examined, it is found that the findings revealed are similar to the findings of question 1. In other words, it means that pre-service teachers are not able to distinguish the concepts of star and planet from one another. It is considered that the pre-service teachers who participated in the study did not receive enough training on basic astronomy subjects which is effective on this situation.

Question 4: "What is a comet?"

The responses of the participants to question 4 were presented in Table 4.

Table 4. Analysis results of the participants for Question 4

\begin{tabular}{ccc}
\hline INTERVIEW QUESTION & FREQUENCY and & \\
\hline & It pulls celestial bodies which enter the gravitational field of the stars. & \\
What is a comet? & It is a formation caused as a result of star explosion. & 25 \\
& A comet is an amalgamation of dust and ice. & 25 \\
\hline
\end{tabular}

When the pre-service teachers' responses to the question "What is a comet?" asked to identify their misconceptions about a comet were examined, it was discovered that 17 pre-service teachers had misconceptions but three teachers could answer the question "What is a comet?". Examples from the responses given for each category were quoted to explain the existing situation.

-PST 6 : "When stars go out of orbit, a streak of light occurs. Because this streak of light resembles to a tail, it is called a falling or shooting star.”

-R: "Can you please clarify stars' going out of their orbits?"

$-P S T_{6}$ : "Due to various reasons, stars rarely go out of their orbit and while moving very fast, they start to burn because of friction and then they leave a trace like a tail."

$-\mathrm{PST}_{2}$ : "While stars are revolving in their orbit, they drag the bodies revolving around them under the influence of gravity. The celestial bodies which are dragged behind them look like a tail and we call these stars a comet."

-PST $T_{3}$ : "In fact, a comet is not a star. They are made of dust and ice."

-R: "Then, why is it called a comet?"

-PST $T_{3}$ : "In my opinion, it is only an unfortunate name."

$-P S T_{18}:$ "When stars explode, they emit light. When they move like that, they look as if they have a tail. Therefore, they are called a comet." 
-R: "In other words, is a comet's tail made up of light? Can you clarify it?"

$-P S T_{18}$ : "No, not exactly like that. In fact, there is no tail. Our eyes see like that."

When participating pre-service teachers' identified misconceptions are examined, it is revealed that most of them answered the question considering the name of the concept. In other words, it means that pre-service teachers are not able to distinguish the concepts of star and planet from one another. It is considered that the existing misconceptions in pre-service teachers are due to the name of the concept.

Question 5: "Can you explain what you know about Big-Bang theory?”

The responses of the participants to question 5 were presented in Table 5.

Table 5. Analysis results of the participants for Question 5

\begin{tabular}{lccc}
\hline \multirow{2}{*}{ INTERVIEW QUESTION } & CATEGORIES & \multicolumn{2}{c}{$\begin{array}{c}\text { FREQUENCY and } \\
\text { PERCENTAGES }\end{array}$} \\
\cline { 3 - 4 } & & f & $\%$ \\
\hline \multirow{2}{*}{$\begin{array}{c}\text { Can you explain what you know } \\
\text { about Big-Bang theory? }\end{array}$} & The theory tells that the sun exploded and formed the planets. & 3 & 15 \\
& It is a theory that explains the formation of the universe. & 4 & 20 \\
\hline
\end{tabular}

When the pre-service teachers' responses to the question "Can you explain what you know about Big-Band theory?" asked to describe their misconceptions about Big-Bang theory were examined, it was discovered that 16 pre-service teachers had misconceptions but four teachers could answer the question "Can you explain what you know about Big-Band theory?" correctly. Examples from the responses given for each category were quoted to explain the existing situation.

-PST $T_{2}$ : "It is a theory which explains the formation of the planets."

-R: "Why do you think of the formation of planets when it comes to Big-bang theory?"

$-\mathrm{PST}_{2}$ : "Yes. Because scientists in the books I have read explain the formation of the Earth and other planets with Big-Bang theory."

-PST 6 : "Big-Bang theory explains how the universe began."

-R: "Can you clarify it?"

-PST.: "It explains how the structure made of dust and gas cloud at the very beginning became the universe and also it tells the stages during this formation."

$-P S T_{19}$ : "It is a theory which explains that the sun was a super massive object and there was a giant explosion of the sun. It broke into pieces, thus forming the planets."

-R: "Do you mean that all the planets were considered to have been formed due to the explosion of the sun?"

$-P S T_{19}$ : "No. What I mean with the sun is the stars. When the sun or the other stars got too warmer, they exploded and broke up into pieces. These pieces cooled and formed the planets. Big-Bang theory explains this phenomenon."

The responses of the pre-service teachers reveal that they were not able to distinguish between the concepts of the stages of formation of stars and the universe and the formation of universe. It is regarded that because the pre-service teachers could not tell the differences, they have misconceptions.

Question 6: "Why was Pluto demoted to the status of a dwarf planet?"

The responses of the participants to question 6 were presented in Table 6.

Table 6. Analysis results of the participants for Question 6

\begin{tabular}{|c|c|c|c|}
\hline \multirow{2}{*}{ INTERVIEW QUESTION } & \multirow{2}{*}{ CATEGORIES } & \multicolumn{2}{|c|}{$\begin{array}{l}\text { FREQUENCY and } \\
\text { PERCENTAGES }\end{array}$} \\
\hline & & f & $\%$ \\
\hline \multirow{3}{*}{$\begin{array}{l}\text { Why was Pluto demoted to the status of } \\
\text { a dwarf planet? }\end{array}$} & I have no idea & 4 & 20 \\
\hline & Because it is small? & 9 & 45 \\
\hline & Because it is too far. & 7 & 35 \\
\hline
\end{tabular}

When the pre-service teachers' responses to the question "Why was Pluto demoted to the status of a dwarf planet?" asked to identify their misconceptions about Pluto were analysed, it was discovered that all pre-service teachers lacked knowledge rather than having misconceptions. Examples from the responses given for each category were quoted to explain the existing situation. 
$-P S T_{12}$ : "I know that Pluto used to be a planet but now it is classified as a dwarf planet. But, I have no idea why it is demoted to the status of a dwarf planet. Is it because it is a much smaller planet?"

-R: "The information that Pluto was the smallest planet among the nine planets in the solar system before it was classified as a dwarf planet is true. However, in your opinion, is that the reason why it is now classified as a dwarf planet?"

-PST ${ }_{12}$ : "I don't know. Moreover, I'm not sure whether my answer is correct or not. I just guessed."

-PST 15. "I have no idea about this subject."

$-P S T_{18}:$ "Because it is the farthest to the Earth, it is considered a dwarf planet."

-R: "So, if a new planet is discovered much further or at the same distance as Pluto, will it be classified as a dwarf planet?"

-PST $18:$ "Possibly. But if this new planet has a large mass, it can be considered a normal planet. But, I'm confused. I don't know."

As understood from the responses, pre-service teachers do not have enough knowledge about the subject. Classification of Pluto as a dwarf planet frequently appears on printed and visual media. However, it is considered that its reasons were not examined and this affected students' responses.

Question 7: "What comes to your mind when talking about astronaut and astronomer?"

The responses of the participants to question 7 were presented in Table 7.

Table 7. Analysis results of the participants for Question 7

\begin{tabular}{|c|c|c|c|}
\hline \multirow{2}{*}{ INTERVIEW QUESTION } & \multirow{2}{*}{ CATEGORIES } & \multicolumn{2}{|c|}{$\begin{array}{c}\text { FREQUENCY and } \\
\text { PERCENTAGES }\end{array}$} \\
\hline & & $\mathbf{f}$ & $\%$ \\
\hline \multirow{2}{*}{$\begin{array}{l}\text { What comes to your mind when } \\
\text { talking about astronaut and } \\
\text { astronomer? }\end{array}$} & Astronaut and astronomer are the same concepts. & 9 & 45 \\
\hline & American space explorers are astronauts and Russian space explorers are astronomers. & 11 & 55 \\
\hline
\end{tabular}

Regarding the question "What comes to your mind when talking about astronaut and astronomer?" asked to identify pre-service teachers' misconceptions about the concepts of astronaut and astronomer; the responses revealed that all pre-service teachers had misconceptions. Examples from the responses given for each category were quoted to explain the existing situation.

PST $_{5}$ : "I have heard the word astronaut a lot but the word astronomer has not been used widely. However, they both mean the same thing."

$-\mathrm{PST}_{2}$ : "American space explorers are called astronauts and Russian space explorers are called astronomers."

-R: "Are you sure?"

-PST 2 : "Yes. I am sure. Yuri Gagarin was the first astronomer to journey into outer space and he was Russian."

Most pre-service teachers state that the concepts of astronaut and astronomer are the same. It is considered that the daily language used might be responsible for this condition. A few pre-service teachers had misconceptions between the concepts of cosmonaut and astronaut. It is considered that because of the information that the first human to journey into space was Russian, they tried to create a context between these two concepts.

Question 8: "What does the death of a star mean?"

The responses of the participants to question 8 were presented in Table 8 .

Table 8. Analysis results of the participants for Question 8

\begin{tabular}{lcc}
\hline \multirow{2}{*}{ INTERVIEW QUESTION } & CATEGORIES & \multicolumn{2}{c}{$\begin{array}{c}\text { FREQUENCY and } \\
\text { PERCENTAGES }\end{array}$} \\
\cline { 2 - 4 } What does the death of a star \\
mean? & Formation of new planets. & 6 \\
\hline & I have no idea. & 30 \\
\hline
\end{tabular}

When the pre-service teachers' responses to the question "What does the death of a star mean?" asked to identify their misconceptions about the life cycle of stars were explored, 15 pre-service teachers had misconceptions and five pre-service teachers stated that they did not have any information about the subject. Examples from the responses given for each category were quoted to explain the existing situation. 
$-P S T_{17}:$ "Stars have existed since the existence of the universe and each passing day they have cooled and become a planet. This event is called the death of stars."

-PST 4 : "I have no information about this subject."

$-P S T_{8}$ : "If stars are too far away to be seen, they are called death stars."

-R: "Do you mean that if we don't see the stars, they are dead?"

$-P S T_{8}:$ "Not exactly. However, the universe continues to expand and as result of this expansion, stars continuously move farther away. When stars move further away and we do not see them, it is called the death of stars. This death is not like the death of a living being. It means that we will not be able to see them and its light will not reach the Earth anymore."

Most of the pre-service teachers perceive the death of stars as vanishing. To people, death means the termination of all biological functions that sustain a living organism. For this reason, it is thought that pre-service teachers attribute different meanings to the death of stars.

As a result of the interviews, the pre-service teachers' misconceptions on basic astronomy subjects were identified and presented below as main themes in Table 9.

Table 9. Pre-service Teachers' Misconceptions on Basic Astronomy Subjects

\begin{tabular}{|c|c|}
\hline SUBJETS & MAIN THEMES \\
\hline \multirow{2}{*}{ Stars } & They are the planets which emit light they take from the sun. \\
\hline & They are the planets which emit light by themselves. \\
\hline Space and Universe & $\begin{array}{c}\text { The space is the place that can be seen by a naked eye, but the universe cannot be seen with a naked } \\
\text { eye. }\end{array}$ \\
\hline \multirow[t]{2}{*}{ Planets } & $\begin{array}{l}\text { Human beings can travel to space but they cannot go to the universe. } \\
\text { They are the stars which completed their life cycle. }\end{array}$ \\
\hline & $\begin{array}{l}\text { They are celestial bodies which have an atmosphere. } \\
\text { It pulls celestial bodies which enter the gravitational field of the stars. }\end{array}$ \\
\hline Comet & It is a formation caused as a result of star explosion. \\
\hline Big-Bang Theory & $\begin{array}{l}\text { It is a formation which occurs when stars fall out of the orbit. } \\
\text { It is a theory that tells that the sun exploded and formed the other planets. } \\
\text { It is a theory that explains the formation of the universe. }\end{array}$ \\
\hline \multirow{2}{*}{ Planet Pluto } & It is a dwarf planet because it is small. \\
\hline & It is a dwarf planet because it is too far away from the Earth. \\
\hline \multirow{2}{*}{ Astronaut and Astronomer } & The concepts of astronaut and astronomer are the same. \\
\hline & $\begin{array}{l}\text { American space explorers are astronauts and Russian space explorers are astronomers. } \\
\qquad \text { New planets are formed. }\end{array}$ \\
\hline The Death of Stars & Stars vanish by moving further away and it is called the death of stars. \\
\hline
\end{tabular}

3.2 Using Micro-teaching Method Supported by Educational Technologies

At the beginning of the spring term, 20 pre-service science teachers were given the following science topics:

The Moon, The Earth, and The Seasons: The Earth, Our planet, The Earth's Shape, The Structure of Earth's Materials and Their Properties.

The Earth, The Sun, and The Moon: The Shape and Size of the Sun, Earth and Moon, The Movement of the Earth, The Movement of the Moon.

What Composes the Earth's Crust: Rock and Mines, Fossils, Soil Types and Erosion Underground and Surface Water, Natural Monuments.

Solar System and Beyond: Space Puzzle: Celestial Bodies in the Space, Solar System and Planets, Space Explorations.

Natural Processes: The Earth's Formation Process, Plate Tectonics, Weather Events.

From Stars to Quasar: Stars, Classification of Stars, Spiral Galaxy, Expansion of the Universe and its Age.

The pre-service teachers made the necessary preparations for the given topics (literature review, lesson plan about the topic, developing and designing an appropriate material and so on) and they presented the lessons via micro-teaching method benefiting from educational technologies for 12 weeks. In addition to the materials they designed, they used relevant animations about the topics. The data sources the pre-service teachers obtained were given below:

http://www.dailymotion.com/video/x6ag7u.gezegen-animasyon.tech

http://www.dersizlesene.com/Fen-Animasyonlari-Izle/Gunes-Sistemi-Ve-Gezegenler-1192.html

http://www.dustbunny.com/afk/planets

http://www.esa.int/esaKIDSen/SEMCM9WJD1EOurUniverse0.html

http://www.fen1.com/etkinlik-canlandirmalari/119-g-sistemi-modeli-olual

http://www.forgefx.com/casestudies/prenticehall/ph/solar_system/solarsystem.htm 
http://www.frontiernet.net/ kidpower/planets.html http://www.kidskonnect.com/subject-index/15-science/95-planets.html http://www.solarsystemscope.com http://www.sosyal-bilgiler.com/flash-animasyonlar/357-gunes-sistemi-ve-gezegenler-animasyonu.html http://highered.mheducation.com/sites/007299181x/student_view0/chapter2/seasons_interactive.html http://ww2.valdosta.edu/ cbarnbau/astro_demos/frameset_seasons.html http://ww2.valdosta.edu/ cbarnbau/astro_demos/frameset_seasons.html http://ww2.valdosta.edu/ cbarnbau/astro_demos/frameset_seasons.html http://ww2.valdosta.edu/ cbarnbau/astro_demos/frameset_seasons.html https://www.youtube.com/watch?v=W47Wa7onrIQ

During the presentations of the course, the pre-service teachers were not interfered. All the implementations were carried out under the supervision of the researcher. The videos which were recorded via interviewing the pre-service teachers at the end of each lesson were watched and feedback about the presentations was given. The researcher mentioned the weaknesses he observed and offered some suggestions. Then, a meeting was held with all the pre-service teachers, the presentations were watched again, and the pre-service teachers were asked to evaluate each other. During these meetings, it was observed that the importance and necessity of using educational technologies stood out. Moreover, regarding the feedback, many pre-service teachers frequently stated that they could understand some topics which they had difficulty in comprehending easily with the animated demonstrations.

\subsection{Findings Obtained from the Interviews Carried out at the end of the Interviews}

After the implementation of micro-teaching method which was supported by educational technologies for 12 weeks, the interview questions were administered to identify whether the misconceptions which pre-service teachers had were eliminated or not and the findings obtained as a result of the analysis of the responses to the questions were given below.

Question 1: "What is a star?"

At the end of the research, when the pre-service teachers' responses to the question "What is a star?" which aimed at identifying whether their misconceptions on a star were eliminated or not were examined, it was revealed all the pre-service teachers answered the question correctly. Examples from the responses given for each category were quoted to explain the existing situation.

$-P S T_{11}$ : "Stars are celestial bodies which emit light and heat as a result of releasing energy due to the transformation of elements in their structures."

$-P S T_{20}$ : "Stars convert hydrogen atoms into helium atoms due to fusion reactions and thus releasing energy that traverses the star's interior and then radiates into space. In other words, stars are celestial bodies which are natural light sources."

It was understood from the given responses that the misconceptions which 15 pre-service teachers had about stars were completely corrected with micro-teaching practice supported by educational technologies. Moreover, it was found that the pre-service teachers who answered the question correctly at the beginning gained comprehensive knowledge about the topic. It is considered that animations were quite effective for this development. Aksan and Çakır (1992) and Sevim (2013) obtained effective results using micro-teaching method in their studies.

Question 2: "What comes to your mind about space and universe?"

At the end of the study when the pre-service teachers' responses to the question "What comes to your mind about space and universe?" asked to identify whether their misconceptions about space and universe were eliminated or not were examined, all the pre-service teachers answered the question correctly.

Some of the responses given by the pre-service teachers to explain the existing condition were quoted below.

$-P S T_{1}$ : "While the zone out of the Earth's boundary is called space, the universe is the zone including the Earth."

$-P S T_{12}$ : "The universe includes everything that exist and all matter. The space does not include our world."

$-P S T_{17}$ : "The space is everywhere except for the Earth, but it we consider our world, it becomes the universe."

It is considered that in addition to micro-teaching practice, the pre-service teachers who participated in the study found this subject more interesting and they both were effective in eliminating pre-service teachers' existing misconceptions at the beginning. Similar results were obtained from the studies carried out by Gürses, Bayrak, Yalçın, Açıkyıldız and 
Doğar (2005) and Kazu (1999).

Question 3: "What is a planet?"

At the end of the study when the pre-service teachers' responses to the question "What is a planet? " asked to identify whether their misconceptions about a planet were eliminated or not were examined, it was revealed that all the pre-service teachers answered the question correctly. Some of the responses given by the pre-service teachers to explain the existing condition were quoted below.

$-P S T_{3}$ : "A planet is a celestial body moving in an elliptical orbit around a star."

$-P S T_{10}$ : "The planets revolve around the sun in elliptical orbits. There are two centres in elliptical orbits. In one of these centres, there is the sun and the celestial bodies moving in elliptical orbits are called a planet."

-PST 14: "A planet is a celestial body which orbit due to stars' force of gravity and move in an elliptical orbit around a star."

It is regarded that frequently used educational technologies, visual representations and the models generated about the subject of planet were effective for all of the pre-service teachers to give correct and scientific answers to the question after the implementations. Moreover, it was identified with the study conducted by Sevim (2013) that implementation of micro-teaching method had positive effects on eliminating misconceptions.

Question 4: "What is a comet?"

At the end of the study when the pre-service teachers' responses to the question "What is a comet?" asked to identify whether their misconceptions about a comet were eliminated or not were examined, it was revealed that all the pre-service teachers answered the question correctly. Some of the responses given by the pre-service teachers to explain the existing condition were quoted below.

-PST: "Comets are composed of water and gases and they have been called icy mud balls or dirty snowballs. As they approach the sun, they begin to melt leaving behind a tail."

-PST 11 : "In fact, a comet is not a star. Comets are composed of ice and gases. As they get closer to the sun, some of their ices melt and form a tail."

$-P S T_{15}$ : "In fact, comets are not stars but they are called comets. We can see them when they get closer to the sun. When they approach the sun, the dust and frozen ices in comets begin to melt and they develop a tail. That's why they are called comets."

This question indicated that micro-teaching made important contributions to correct misconceptions. However, it is considered that if the concept of comet causes misunderstandings, any method which will explain the concept correctly will be effective.

Question 5: "Can you explain what you know about Big-Bang theory?"

At the end of the study when the pre-service teachers' responses to the question "Can you explain what you know about Big-Bang theory?" asked to identify whether their misconceptions about Big-Bang theory were eliminated or not were examined, it was revealed that all the pre-service teachers answered the question correctly. Some of the responses given by the pre-service teachers to explain the existing condition were quoted below.

-PST : "There are two theories which explain the formation of the universe and Big-Bang theory is the accepted one. Big-Bang theory explains how the universe began."

$P S T_{17}$ : "At the beginning universe, formed from a cloud of dust and gas, began to expand with a big explosion. Big-Bang theory explains this formation."

During the implementations, it was noticed that Big-Bang theory was explained with animations and the pre-service teachers were quite interested in the subject. It is thought that in addition to micro-teaching, the animations had an important effect on correcting misconceptions.

Question 6: "Why was Pluto excluded from the planet classification and demoted to the status of a dwarf planet?"

Before micro-teaching, when the pre-service teachers' responses to the question "Why was Pluto excluded from the planet classification and demoted to the status of a dwarf planet?" asked to identify whether their misconceptions about Pluto were eliminated or not were examined, it was revealed that all the pre-service teachers lacked knowledge rather than having misconceptions. After micro-teaching, when the same question was asked to the pre-service teachers, it was found that still three teachers had lack of knowledge about the subject. Some of the responses given by the pre-service teachers to explain the existing condition were quoted below.

-PST,: "Because Pluto was much smaller than the other eight planets in the solar system and it did not have a satellite, 
it was classified as a dwarf planet."

17 pre-service teachers could answer the question "Why was Pluto excluded from the planet classification and demoted to the status of a dwarf planet?" correctly. Some of the responses given by the pre-service teachers to explain the existing condition were quoted below.

-PST $T_{5}$ : "For a celestial body to be classified as a planet in the solar system, it must revolve around the sun in an elliptical orbit, it must have enough gravity to make it almost round, and it must have the power to send out objects that enter their orbit. However, Pluto must be surrounded by objects of similar size and characteristics in its orbit and it should have a feature that can either send out or sling away the objects with its gravitational force. That's why The International Astronomical Union (IAU) downgraded the status of Pluto to that of a dwarf planet in a meeting held in Prague in 2006."

-PST 4 : "Pluto is a Kuiper Belt object and this belt is home to many celestial bodies with the similar sizes as Pluto. Therefore, Pluto was excluded from the planet classification in 2006."

It was understood from the given responses that micro-teaching method was an effective method both in eliminating misconceptions and promoting academic achievement. This result corresponds with the studies conducted by Aksan and Çakır (1992); Gürses et al.(2005); Kazu (1999); Sevim (2013) which reveal that micro-teaching method is an effective method which promote academic achievement.

Question 7: "What comes to your mind when talking about astronaut and astronomer?"

At the end of the study when the pre-service teachers' responses to the question "What comes to your mind when talking about astronaut and astronomer?" asked to identify whether their misconceptions about an astronaut and an astronomer were eliminated or not were examined, it was revealed that 18 pre-service teachers answered the question correctly but two teachers still had misconceptions. Some of the responses given by the pre-service teachers to explain the existing condition were quoted below.

$-P S T_{3}$ : "An astronaut is a person trained to journey into the outer space to carry out explorations by a spacecraft. An astronomer is a scientist who studies the space beyond Earth's atmosphere."

-PST 9: "An astronaut is a concept used for the space explorers who travel to the space. An astronomer is a name given to the researchers who do research on space with astronomy research tools such as telescope and with knowledge and photographs sent back to the Earth by the astronauts."

$-P S T_{13}:$ "Both concepts are synonymous with each other and they are used for space researchers."

Although all the pre-service teachers who participated in the study had misconceptions about the subject at the beginning, the misconceptions which 18 pre-service teachers had were corrected after the implementations. This proves once again that micro-teaching is quite an effective method to eliminate misconceptions. However, the results yielded that two teachers still had misconceptions. During the implementations about the subject, it was found that these two teachers were unprepared while attending the lessons. It is considered that the existing misconceptions were not eliminated because of this.

Question 8: "What is the death of stars?"

At the end of the study when the pre-service teachers' responses to the question "What is the death of stars?" asked to identify whether their misconceptions about the Life Cycle of Stars were eliminated or not were examined, it was revealed that 16 pre-service teachers answered the question correctly but four teachers still had misconceptions. Out of four pre-service teachers, three of them had misconceptions before the implementation. However, one pre-service teacher stated that she had no idea about the subject at the beginning of the implementations. Some of the responses given by the pre-service teachers to explain the existing condition were quoted below.

$-P S T_{12}$ : "As the core of stars runs out of fuel, nuclear fusion does not occur on its outer layers, but it continues to burn near the core. As a result of this burning in the core, a light is formed and the upper layer prevents this light from being scattered around. Therefore, the star cannot be seen. This phenomenon is called the death of a star."

-PST 14: "A star begins its life as cloud of dust and gas known as nebulae and gravity causes the dust and gas of nebulae to clump together and pulls towards inward. Then, nuclear fusion begins due to the increase of pressure and temperature and hydrogen converts into helium. There is a balance between the thermal pressure (outward) and the weight of the material above pressing downward (inward). The internal pressure of the star supplies the outward energy which counteracts the inward pressure of its gravity, thus preventing the collapse. This balance is called hydrostatic equilibrium. When the star consumes the fuel, the internal pressure cannot prevent the collapse and the star collapses towards inward. As a result of this, based on the size of the star, it ends up as a white dwarf, a blue dwarf, a neutron star or a black hole. This phenomenon is called the death of a star." 
$-P S T_{5}:$ "Stars emit light and heat around themselves by burning the matter in their structures. However, when this fuel starts to run out, the light and heat cools down. As the universe expands, stars move further away from us each day. Due to the effect of these two reasons, the starlight does not reach the Earth, in other words, when we are not able to see them, we understand that they are dead stars."

At the beginning of the research, out of 15 pre-service teachers who had misconceptions, misconceptions of 12 pre-service teachers were eliminated, which is quite a good ratio. However, three pre-service teachers' misconceptions could not be corrected. It was noticed that during the implementations these three pre-service teachers were insistent that stars were not alive so their death could not be mentioned. It is considered that these pre-service teachers continued to hold their misconceptions because of their insistence. At the beginning, out of four teachers who stated that they had no idea about the subject, three of them could give scientific and illuminating answers to the question. This condition demonstrates that micro-teaching method has a positive effect not only on eliminating misconceptions but also promoting academic achievement. One pre-service teacher stated that he had no idea about the subject in the first interview. However, the second interview carried out revealed that he had misconception about the subject. Because this was the last question in the interview, this pre-service teacher may have got bored and also given the response that he had no idea about the subject as he wanted the interview to finish as soon as possible. For this reason, it was believed that this misconception which was not identified at the beginning still continued and it could be determined in the second interview.

\section{Results and Recommendations}

When the findings obtained from the study which was conducted to identify pre-service teachers' misconceptions on basic astronomy subjects and to reveal the effect of micro teaching method supported with educational technologies on eliminating misconceptions were examined, it was found that the pre-service teachers had misconceptions on basic astronomy concepts. However, regarding the data obtained from the $6^{\text {th }}$ and $8^{\text {th }}$ questions, it was identified that pre-service teachers had lack of knowledge rather than misconceptions on basic astronomy subjects.

It was revealed during the implementations that micro-teaching method offered opportunities to pre-service teachers to see weaknesses in themselves and encouraged them to take responsibility for their learning. This caused pre-service teachers to learn the subjects in-depth and meaningfully and also provided opportunities to replace misconceptions with scientific facts. The interview questions were asked to the pre-service teachers again after the implementations. It was concluded from the data obtained that micro-teaching supported with educational technologies had positive effects on eliminating the identified misconceptions of the pre-service teachers. Moreover, the data obtained from the $6^{\text {th }}$ and $8^{\text {th }}$ questions from the interview form revealed that the implementation of micro-teaching method promoted academic achievement. Undoubtedly, the educational technologies used made contributions to the improvement.

In line with the results obtained in the research study, the following recommendations were made:

It was observed throughout the research that micro-teaching method takes a lot of time and it is not possible to administer micro-teaching with all of the pre-service teachers within the framework of curriculum. In order to solve this problem, the first thing to do is to identify pre-service teachers' misconceptions individually. Then, micro-teaching method must be administered with each pre-service teacher and it must include the misconceptions which the pre-service teacher has.

In parallel with the teaching practice courses included in the $4^{\text {th }}$ grade program of Science Education Department, coordination should be provided with practice schools and micro-teaching should be implemented in real classroom settings.

It was observed with all the implementations that educational technologies were quite effective. In addition to the methods which will be implemented in the studies to eliminate the misconceptions identified in physics subjects or to promote academic achievement, educational technologies must be benefited from.

\section{References}

Aksan, Y., \& Cakır, O. (1992). Pre-Service Teacher Education: A Case Study. The Second International Conference: ELT and Teacher Training in the 1990's: Perspectives and Prospects, 23-25 September, Ankara, Turkey.

Aksoy, N. (2003). Eylrm Araştırması: Eğitimsel uygulamaları İyileştirme ve Değiştirmede Kullanılacak Bir Yöntem. . [Action Research: A Method for Improving and Cganging Educitional Practices]. Kuram ve Uygulamada Ĕ̌itim Yönetimi, 36, 474-489.

Baxter, J. (1989). Children's Understanding of Familier Astronomical Events. International Journel of Science Education, 11(5), 302 -313. http://dx.doi.org/10.1080/0950069890110503

Bell, N. D. (2007). Microteaching: What is it that is going on here? Linguistic and Education, 18(1), 24-40. 
http://dx.doi.org/10.1016/j.linged.2007.04.002

Bisard, W. J., Aron, R. H., Francek, M. A., \& Nelson, B. D. (1994). Assessing Selected Physical Science and Earth Science Misconceptions of Middle School Through University Preservice Teachers: Breaking The Science 'Misconception Cycle'. Journel of Collage Science Education, 24(1), 38- 42.

Bryce, T. G. K., \& Blown, E. J. (2006). Cultural Mediation of Children's Cosmologies: A Longitudinal Study of the Astronomy Concepts of Chinese and New Zealand Children. International Journal of Science Education, 28(10), 1113-1160. http://dx.doi.org/10.1080/09500690500439280

Büyüköztürk, Ş., Kılıç Çakmak, E., Akgün, Ö. E., Karadeniz, Ş., \& Demirel, F. (2013). Bilimsel Araştırma Yöntemleri, PegemA: Ankara.

Dennick, R. (1998). Teaching Medical Educators to Teach: The Structure and Participant Evaluation of the Teaching Improvement Project. Medical Teacher, 20(6), 598-601. http://dx.doi.org/10.1080/01421599880385

Ekiz, D., \& Akbaş, Y. (2005). İlköğretim 6. Sınıf Öğrencilerinin Astronomi ile İlgili Kavramları Anlama Düzeyi ve Kavram Yanılgıları. Milli Ĕ̈itim Dergisi, 165.

Emrahoğlu, N., \& Öztürk, A. (2009). Fen Bilgisi Öğretmen Adaylarının Astronomi Kavramlarını Anlama Seviyelerinin ve Kavram Yanılgılarının İncelenmesi Üzerine Boylamsal Bir Araştırma. [A Longitudinal Research on the Analysis of the Prospective Science Teachers' Level of Understanding the Astronomical Concepts And Their Misconceptions]. Ç.Ü. Sosyal Bilimler Enstitüsü Dergisi, 18(1), 165-180.

Gürbüz, F. (2008). İlköğretim 6. Sinıf Öğrencilerinin "Isı ve Sicaklık" Konusundaki Kavram Yanılgılarının Düzeltilmesinde Kavramsal Değişim Metinlerinin Etkisinin Araştırllmast. [An investigation on the effect of Conceptual Change Text Approach on Removal of 6th Grade Students' Misconceptions About Heat and Temperature]. Yayınlanmamış Yüksek Lisans Tezi, Atatürk Üniversitesi Fen Bilimleri Enstitüsü, Erzurum.

Gürses, A., Bayrak, R., Yalçın, M., Açıkyıldız, M., \& ve Doğar, Ç. (2005). Öğretmenlik Uygulamalarında Mikro Öğretim Yönteminin Etkililiğinin İncelenmesi. Kastamonu Eğitim Dergisi, 13(1), 1-10.

Hall, R., \& Leveridge, M., (1983). The Use of Video in Residential Social Work Staff Development. Social Work Education, 3(1), 15-18. http://dx.doi.org/10.1080/02615478311220131

I'Anson, J., Rodriguez, S., \& Wilson, G. (2003). Mirrors, Reflections and Refractions: The contribution of microteaching to reflective practice. European Journal of Teacher Education, 26(2), 189-199. http://dx.doi.org/10.1080/0261976032000088729

Kalkan H., Kalkan S., \& Ustabaş, R. (2006). Illk ve Orta Öğretim Öğretmen Adaylarının Temel Astronomi Konularındaki Kavram Yanılgıları. VII. Ulusal Fen Bilimleri ve Matematik Eğitimi Kongresi, Gazi Üniversitesi, 6-8 September, Ankara, Turkey.

Kazu, H. (1999). “Öğretmen yetiştirmede mikro öğretim”. 4.Ulusal Eğitim Bilimleri Kongresi Bildiriler, (1). Eskişehir: Anadolu Üniversitesi. Yayın, 1076, 421-433.

Keçeci, T. (2012). İlköğretim öğrencilerinin Astronomiyle İlgili Kavramları Anlama Düzeyi ve Astronomi dersinin Ĕgitim İçin Önemi. 3th International Conference on New Trends in Education and Their Implications, 26-28 April, Antalya, Turkey.

Kikas, E. (1998). The Impact of Teaching on Students' Definitions and Explanations of Astronomical Phenomena. Learning and Instruction, 8(5), 439- 454. http://dx.doi.org/10.1016/S0959-4752(98)00004-8

Kinchin, I., \& Alias, M. (2005). Exploiting Variations in Concept Map Morphology as a Lesson-Planning Tool for Trainee Teachers in Higher Education. Journal of In-service Education, 31(3), 569-592. http://dx.doi.org/10.1080/13674580500200366

Kpanja, E. (2002). A Study of the Effectiveness of Videotape Recording in Microteaching Training. British Journal of Educational Technology, 32(4), 483-486. http://dx.doi.org/10.1111/1467-8535.00215

Mali, G. B., \& Howe, A. (1979). Development of Earth and Gravity Concepts among Nepali Children. Science Education, 63(5), 685-91. http://dx.doi.org/10.1002/sce.3730630514

Marble, S., \& Fowler, M. Ed. (1993). Astronomy: Minds-on the Universe. Supplemental Teaching Activities for Grades K-8. Washington DC: Office of Educational Research and Improvement. (ERIC No. ED 406 240).

Mellon, E. K., \& Dence, J. B., (1971). Orientation for Teaching Assistants Using Video Recorded Microteaching. Journal of Chemical Education, 48(10), 674-675. http://dx.doi.org/10.1021/ed048p674

Metcalf, K. K., Hammer, M. A. R., \& Kahlich, P. A. (1996). Alternatives to Field-based Experiences: The Comparative 
Effects of on-campus Laboratories. Teaching and Teacher Education, 12(3), 271-283. http://dx.doi.org/10.1016/0742-051X(95)00037-K

Mills, G. E. (2003). Action Research: A Guide for the Teacher Researcher (2nd ed.). New Jersey: Merrill Prentice Hall.

Munn, P., Johnstone, M., \& Holigan, C. (1990). Pupils' Perceptions of Effective Disciplinarians. British Educational Research Journal, 16(2), 191-198. http://dx.doi.org/10.1080/01411192900160207

Nussbaum, J. (1979). Children's Conseptions of the Earth as a Cosmic Body: A Cross Age study. Science Education, 63(1), 83-93. http://dx.doi.org/10.1002/sce.3730630113

O’Brien, R. (2001), An Overview of Methodological Approach of Action Research, In Roberto Richardson (ed.), Theory and Practice of Action Research, Joao Pesso, Brazil.

Orbay, M., \& Gökdere, M. (2006). Fen Bilgisi ve Sınıf Öğretmenliği Adaylarının Temel Astronomi Kavramlarına İlişkin Bilgi Düzeylerinin Belirlenmesi. VII. Ulusal Fen Bilimleri ve Matematik Eğitimi Kongresi, Gazi Üniversitesi, 6-8 September, Ankara, Turkey.

Şahin, F. (2001). İlköğretim 2. Sınıf Öğrencilerinin Uzay Hakkındaki Bilgilerinin Değerlendirilmesi. SDÜ Burdur Ĕ̈itim Fakültesi Dergisi, 2, 156-169.

Saunders, W., Gall, M. D., Nielson, E., \& Smith, G. (1975). The Effects of Variations in Microteaching on Prospective Teachers' Acquisition of Questioning Skills. Journal of Educational Research, 69(1), 3-8. http://dx.doi.org/10.1080/00220671.1975.10884815

Sevim, S. (2013). Mikro-öğretim Uygulamasının Öğretmen Adayları Gözüyle Değerlendirilmesi. [Evaluation of Microteaching Applications through Student Teacher' Views]. Dicle Üniversitesi Ziya Gökalp Eğitim Fakültesi Dergisi, 21, 303-313.

Simbo, F. K. (1989). The Effects of mMİcroteaching on Student Teachers' Performance in the Actual Teaching Practice Classroom. Educational Research, 31(3), 195-200. http://dx.doi.org/10.1080/0013188890310305

Trumper, R. A. (2001). A Cross-College Age Study of Science and Nonscience Students' Conceptions of Basic Astronomiy Concepts in Preservice Training for High-School. Teachers Journal of Science Education and Technology, 10(2), 189- 195.

Ucar, S. (2012). The search for intervention method to transfer astronomy content knowledge. World Confernce on Educational Sciences (WCES).

Ucar, S., \& Demircioglu, T. (2010). Astronomiye Yönelik Tutumların Bir Dönem Boyunca Alınan Astronomi Dersi ve Program Boyunca Alınan Fen Dersleriyle Değişiminin İncelenemesi, 19. Eğitim Bilimleri Kurultayı. Kıbrıs: Uluslararası Kıbrıs Üniversitesi.

Ucar, S., \& Demircioglu, T. (2011).Changes in Preservice Teacher Attitudes Toward Astronomy Within a Semester-Long Astronomy Instruction and Four-Year-Long Teacher Training Programme. Journal of Science Education and Technology, 20(1), 65-73.

Ünsal, Y., Güneş, B., \& Ergin, İ. (2001). Yükseköğretim Öğrencilerinin Temel Astronomi Konularındaki Bilgi Düzeylerinin Tespitine Yönelik Bir Araştırma. [A Study to Investigate the Fundamental Astronomy Knowledge Levels of Undergraduate Students]. Gazi üniversitesi Gazi Eğitim Fakültesi Dergisi, 21(3), 47-60.

Vosniadou, S., \& Brewer, W. (1992). Mental Models of the Earth: A Study of Conceptual Change in Childhood. Cognitive Physchology, 24, 535-585.

Yıldırım, A., \& Şimşek, H. (2013). Sosyal Bilimlerde Nitel Araştırma Yöntemleri. Seçkin Yayınevi: Ankara.

Yin, R. K. (2003). Case Study Research Design and Methods (Third Edition). New Delhi: London.

Yürük, N., Cakır, O. S., \& Geban, O. (2000). Kavramsal Değişim Yaklaşımının Hücresel Solunum Konusunda Lise Öğrencilerinin Biyoloji Dersine Karşı Tutumlarına Etkisi. 4. Fen Bilimleri Eğitimi Kongresi, 6-8 October, Ankara, Turkey.

Zeilik, M., Schau, C., \& Mattern, N. (1998). Misconceptions and Their Change in University-Level Astronomy Courses. The Physics Teacher, 36(2), 104-107. http://dx.doi.org/10.1119/1.880056 